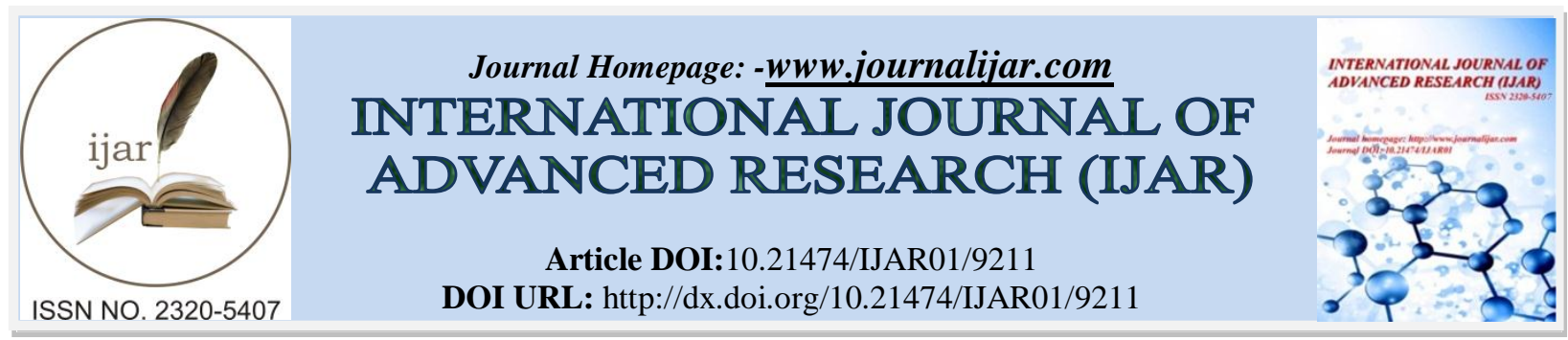

RESEARCH ARTICLE

\title{
INTUSSUSCEPTION CAUSED BY AN ADENOMYOMA OF THE ILEUM: A CASE REPORT.
}

\author{
Ahmed Elguazzar ${ }^{1}$, Amine Azami², Mohamed Lahkim ${ }^{1}$, Ahmed Elkhader ${ }^{1}$, Rachid Elbarni ${ }^{1}$ And Abdessamad \\ Achour'. \\ 1. Department of general surgery, Avicenna Military Hospital, Marrakesh. \\ 2. Department of pathology, Avicenna Military Hospital, Marrakesh.
}

\section{Manuscript Info}

Abstract

Manuscript History

Received: 05 April 2019

Final Accepted: 07 May 2019

Published: June 2019

Copy Right, IJAR, 2019,. All rights reserved.

\section{Introduction:-}

Acute intussusception is defined by the penetration of an intestinal segment (invaginated loop) into the downstream segment (receiving loop). It was originally described by Bardette in 1674 [1].It is the leading cause of intestinal obstruction in infants where it most often occurs in a benign or idiopathic pathological situation [2].In adults, unlike children, intussusception is rare, accounting for only 1 to $5 \%$ of etiologies of intestinal obstruction [3] with an organic cause in $70 \%$ to $90 \%$ of cases, $65 \%$ of wich are from a neoplastic nature [4]. Consequently, in adults the treatment is surgical based on intestinal resection, with however a still open debate concerning the necessity or not of a prior reduction of the intussusceptum [3]. The prognosis is related on the one hand to the precocity of the management and on the other hand to the benign or malignant nature of the causal affection.

We report and discuss the case of a young woman with acute intestinal intussusception caused by an adenomyoma of the wall of the distal ileum: a very rare benign intestinal tumor.

\section{Case Report}

Ms. FO, a 28 year old Moroccan women, with no particular medical history, breastfeeding (4 months after a vaginal delivery), was admitted to the emergency department with a 12 -hours history of intense abdominal pain, sitting mostly on the right, and uncontrollable vomiting, intestinal transit was preserved.

The patient's physical status on admission was as follows: body temperature 37.2, blood pressure 135/75, and pulse rate 72 beats /min. physical examination indicated a pain of the right iliac fossa and diffuse abdominal tenderness without distension or muscular rigidity. The hernia orifices were free, the rest of the clinical examination was normal.

His laboratory data on admission were as follows: white blood cell count $17000 / \mathrm{mm} 3$, hemoglobin $9.3 \mathrm{~g} / \mathrm{dl}$, platelets 180000/mm3, C-reactive protein $3.66 \mathrm{mg} / \mathrm{l}$, without hydroelectrolytic disorders.

The abdominal ultrasound showed intestinal thickening at the level of the right iliac fossa and on peri-umbilical, with heterogeneous echogenic plaques intramural. Contrast-enhanced computed tomography (CT) showed an intussusception of the terminal ileum with an intestinal dilatation upstream, without hydro-aeric level, or signs of parietal suffering of the intestine (Target sign ) (fig.1). 


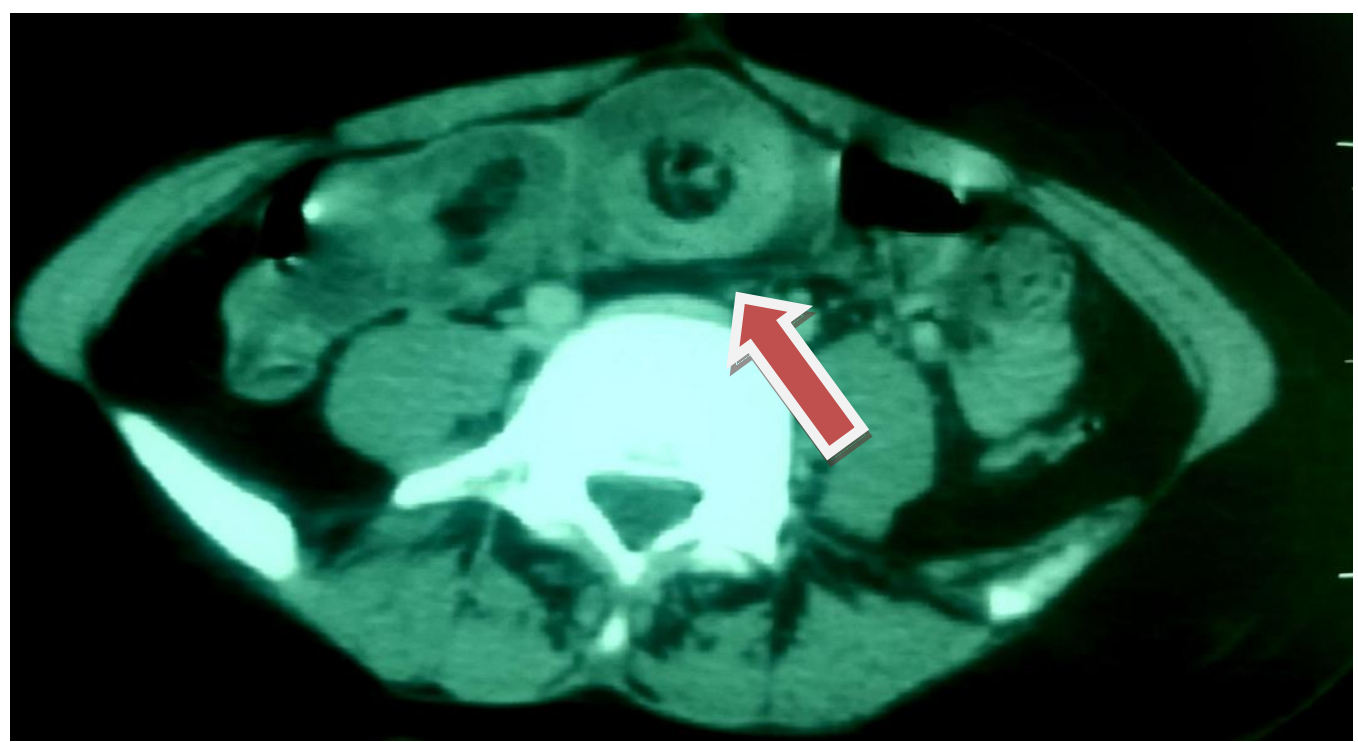

Fig 1:-Enhanced CT of the abdomen and pelvis showed an intussusception of the terminal ileum (arrow).

Open laparotomy was performed and showed non-reducible ileocecal invagination with necrosis of the intussusceptum and caecum (fig.2) .Downstream, the colon was flat whereas upstream the small intestine was distended. There was satellite mesenteric lymphadenopathy.

Ileocecal resection was performed removing the ischemic segments, with immediate ileocolic anastomosis and abdominal drainage. The patient's postoperative course was uneventful. Subsequent control was satisfactory.

Surgical specimen was addressed for pathological examination. At gross examination, the submucosal tumour appeared well-defined, whitish and soft and solide. It measured $1.5 \times 1.3 \mathrm{~cm}$. The microscopic examination showing a tumor located in the submucosa and composed of glandular and tubular structures lined by regular columnar epithelium and surrounding by smooth muscle bundles(figure 3 -a). Immunohistochemical examination revealed a strong expression of CK 7 (figure 3-b) and CK 19 (figure3-c) in the epithelial proliferation. The CK20 was negative in the proliferation and positive in the intestinal epithelium. The smooth muscle bundles are positive for the smooth muscle actin (figure $3-d$ ). These features were compatible with the diagnosis of adenomyoma of the ileum (Figure 3).

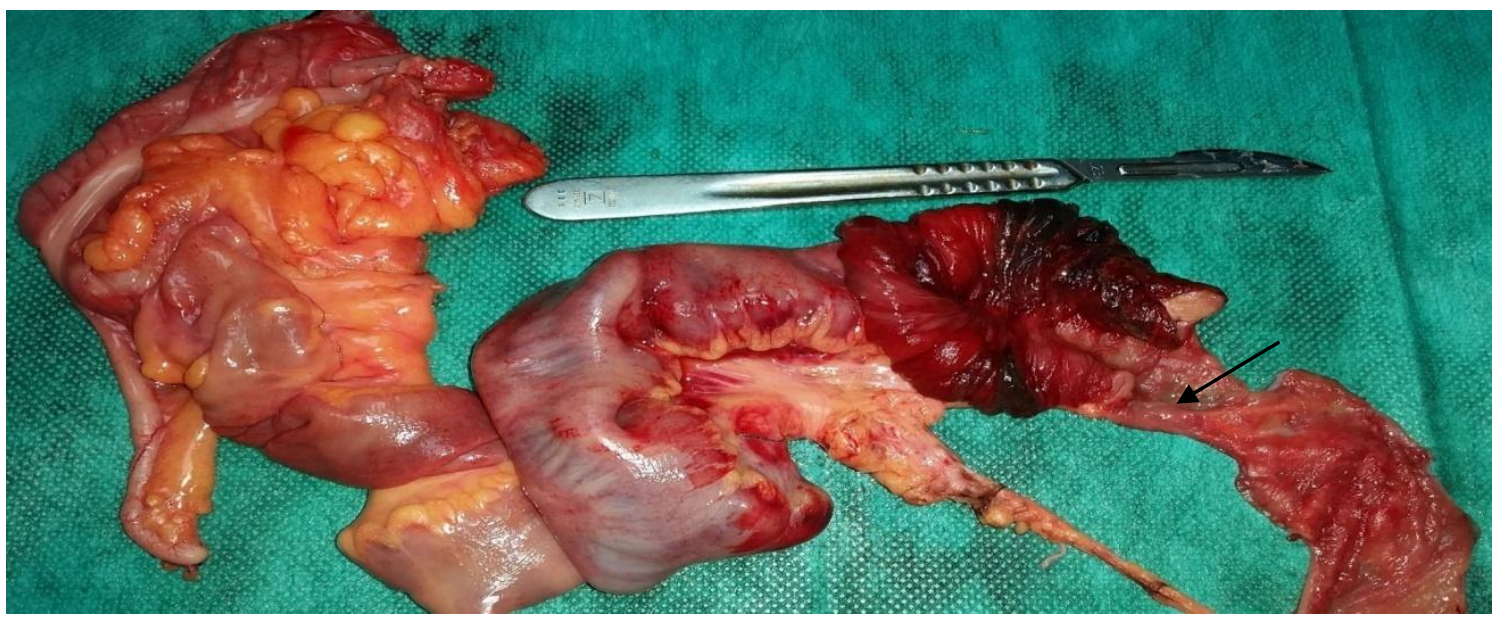

Fig 2:-Specimen of ileocaecal resection with evidence of an ileal tumor ( arrow) : lead point for intussusception. 


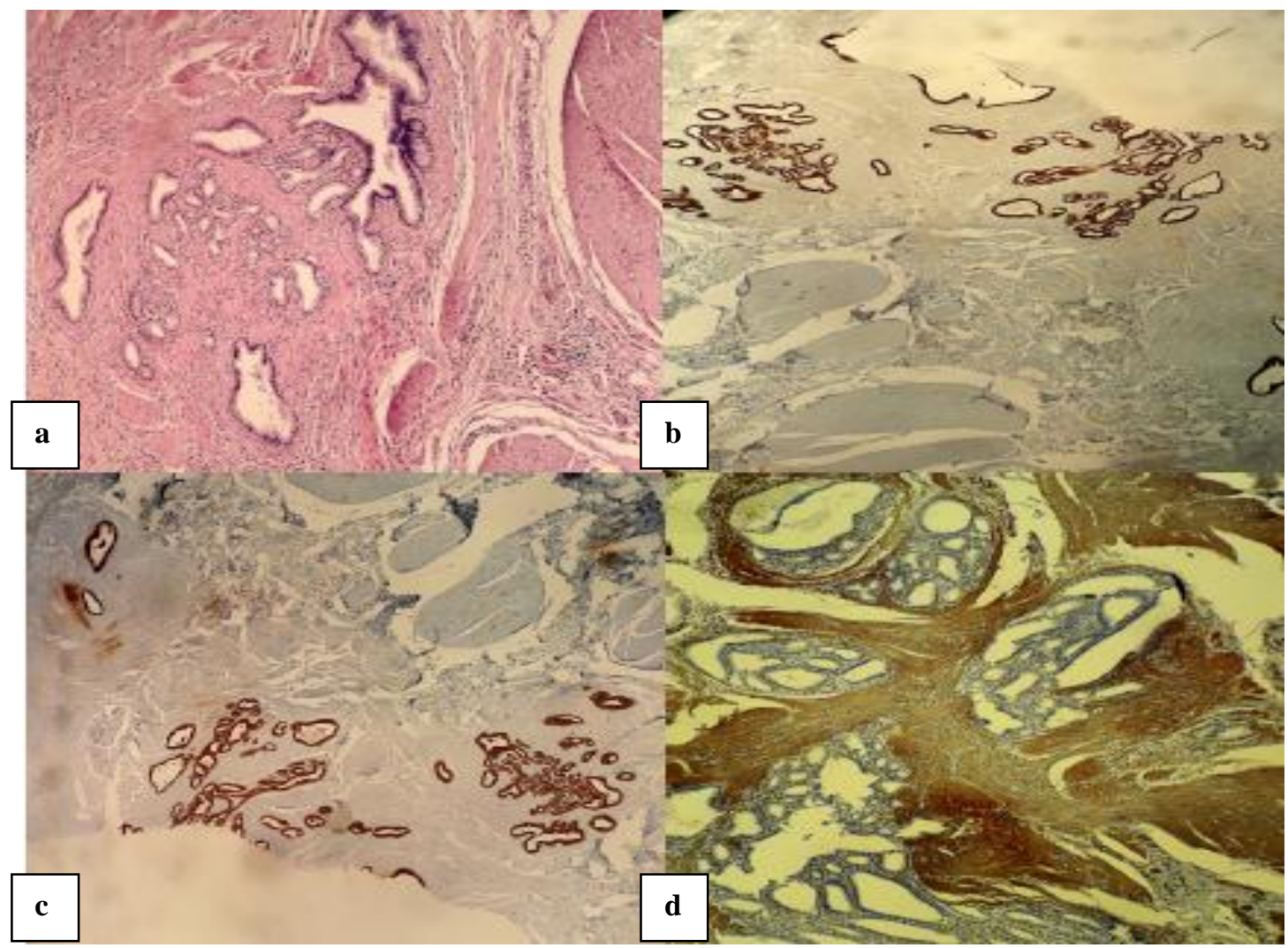

Fig 3:-Histological features and immunohistochemical profile of the tumor: (a): the tumor composed of glandular structures surrounded by bundles of smooth muscle cells in the submucosa of the ileum. (Hematoxylin-eosin stain, $\times 4)$. The tumor cells express CK 7 (b) and CK 19 (c). The bundles of smooth muscle cells are strongly positive of smooth muscle actin (d).

\section{Discussion:-}

Generally, adult represent approximately $5 \%$ of all intussusception cases and account for only $1-5 \%$ of obstructions in adults [3].

The clinical signs of intussusceptions including the classic triad associating paroxysmal abdominal pain, bloody diarrhea and palpable mass on examination, are found in children but are very rarely present in adults, estimated at 9.8\% [5] . In fact, in adults, the presentation is most often non-specific with symptoms that can evolve in a chronic mode, including nausea, vomiting, constipation, slimming or simple abdominal distension [6].

The diagnosis of intussusceptions is based primarily on abdominal imaging which includes ultrasound or CT. The first examination is very widely used in children where its sensitivity and specificity are high. In adults, ultrasound can be limited by obesity or air distention and it is the abdominal computed tomography that seems to be most reliable examination to confirm the diagnosis, in particularly in pauci-symptomatic patients, with sensitivity ranging from $58 \%$ to $100 \%$ [6;7] , it allows to define the location, the nature and sometimes the etiology of Intussusception (showing a underlying tissue lesion) [7]. The two classic images are the "sandwich" image in longitudinal section drawing the head of the invagination and the "roundel" image in cross-section representing the intussusceptum.

Almost $90 \%$ of adult intussusceptions are caused by a pathological condition that serves as a lead point such as carcinoma, polyps, colonic diverticulum, Meckel's diverticulum strictures, or benign neoplasm [6]. Malignancy is present in about 13-47\% of enteric intussusceptions and in 33-62.5\% of colonic intussusceptions [8-10]. it is for this high incidence of malignancy that surgical resection and without radiological decompression is recommended in most adult cases [11].

Our case reports acute intestinal intussusception of the adult secondary to adenomyoma which is a rare benign lesion of the gastrointestinal tact localized at the stomach, small intestine and biliary ducts [12]. Adenomyoma of the 
stomach is usually asymptomatic. Its occurrence in the small intestine is rare in children and extremely rare in adults. It was concluded that ileal adenomyoma often causes intussusception, especially in children, and a tendency towards the incidental discovery of intussusception was noted in adults, although it was not the same for our case. The preoperative diagnosis of intussusceptions is difficult, and the frequency of a correct preoperative diagnosis ranged from 40.7 to $50 \%$ in previous studies [5]. In our case, we were able to establish a preoperative diagnostic with CT.

Below, we summarize the characteristics of the 20 previous cases of adenomyoma of the ileum reported in English language literature (table 1) [13-30 ].

Table 1:-Cases of ileal adenomyoma reported in the English language literature.

\begin{tabular}{|c|c|c|c|c|c|c|c|c|c|}
\hline No. & $\begin{array}{l}\text { First } \\
\text { author }\end{array}$ & $\begin{array}{l}\text { Ye } \\
\text { ar }\end{array}$ & Age & Sex & $\begin{array}{l}\text { Preoperati } \\
\text { ve } \\
\text { diagnosis }\end{array}$ & $\begin{array}{l}\text { Diagnostic } \\
\text { examinati } \\
\text { on }\end{array}$ & $\begin{array}{l}\text { Intraopera } \\
\text { tive } \\
\text { reduction }\end{array}$ & $\begin{array}{l}\text { Intraopera } \\
\text { tive } \\
\text { conditions }\end{array}$ & $\begin{array}{l}\text { Histopatholo } \\
\text { gy }\end{array}$ \\
\hline 1 & $\begin{array}{l}\text { Schwartz } \\
{[13]}\end{array}$ & $\begin{array}{l}195 \\
8\end{array}$ & $\begin{array}{l}8 \\
\text { mont } \\
\text { hs }\end{array}$ & Male & ND & ND & $\mathrm{O}$ & $\begin{array}{l}\text { Intussuscep } \\
\text { tion }\end{array}$ & $\begin{array}{l}\text { Myoepithelial } \\
\text { hamartoma }\end{array}$ \\
\hline 2 & $\begin{array}{l}\text { Benisch [ } \\
14 \text { ] }\end{array}$ & $\begin{array}{l}197 \\
8\end{array}$ & $\begin{array}{l}47 \\
\text { years }\end{array}$ & $\begin{array}{l}\text { Fema } \\
\text { le }\end{array}$ & $\begin{array}{l}\text { Uterine } \\
\text { fibromyom } \\
\text { ata }\end{array}$ & ND & $\mathrm{x}$ & $\begin{array}{l}\text { Incidental } \\
\text { findings }\end{array}$ & adenomyoma \\
\hline 3 & $\begin{array}{l}\text { Rosenma } \\
\text { nn [ 15 ] }\end{array}$ & $\begin{array}{l}198 \\
0\end{array}$ & $\begin{array}{l}2 \\
\text { days }\end{array}$ & $\begin{array}{l}\text { Fema } \\
\text { le }\end{array}$ & $\begin{array}{l}\text { Rupture of } \\
\text { the } \\
\text { intestine }\end{array}$ & $\mathrm{X}$ ray & $\mathrm{x}$ & $\begin{array}{l}\text { Intestinal } \\
\text { atresia }\end{array}$ & $\begin{array}{l}\text { Leiomyomato } \\
\text { us hamartosis }\end{array}$ \\
\hline 4 & Gal [ 16] & $\begin{array}{l}198 \\
6\end{array}$ & $\begin{array}{l}82 \\
\text { years }\end{array}$ & $\begin{array}{l}\text { femal } \\
\text { e }\end{array}$ & $\begin{array}{l}\text { Small } \\
\text { bowel } \\
\text { obstruction }\end{array}$ & $\mathrm{X}$ ray & ND & $\begin{array}{l}\text { intussuscep } \\
\text { tion }\end{array}$ & $\begin{array}{l}\text { Adenomyoma } \\
\text { tous } \\
\text { hamartoma }\end{array}$ \\
\hline 5 & $\begin{array}{l}\operatorname{Kim}[17 \\
]\end{array}$ & $\begin{array}{l}199 \\
0\end{array}$ & $\begin{array}{l}7 \\
\text { years }\end{array}$ & male & $\begin{array}{l}\text { Small } \\
\text { bowel } \\
\text { obstruction }\end{array}$ & $\begin{array}{l}\text { Abdominal } \\
\text { CT, } \\
\text { ultrasound }\end{array}$ & ND & $\begin{array}{l}\text { Intussuscep } \\
\text { tion }\end{array}$ & adenomyoma \\
\hline 6 & Gal [18 ] & $\begin{array}{l}199 \\
1\end{array}$ & $\begin{array}{l}9 \\
\text { mont } \\
\text { hs }\end{array}$ & Male & $\begin{array}{l}\text { Small } \\
\text { bowel } \\
\text { obstruction }\end{array}$ & ND & $\mathrm{O}$ & $\begin{array}{l}\text { Intussuscep } \\
\text { tion }\end{array}$ & adenomyoma \\
\hline 7 & Gal [ 18] & $\begin{array}{l}199 \\
1\end{array}$ & $\begin{array}{l}79 \\
\text { years }\end{array}$ & Male & $\begin{array}{l}\text { Colon } \\
\text { carcinoma }\end{array}$ & ND & $\mathrm{X}$ & $\begin{array}{l}\text { Incidental } \\
\text { findings }\end{array}$ & adenomyoma \\
\hline 8 & $\begin{array}{l}\text { Lamki } \\
{[19]}\end{array}$ & $\begin{array}{l}199 \\
3\end{array}$ & $\begin{array}{l}1 \\
\text { year }\end{array}$ & Male & $\begin{array}{l}\text { Intussuscep } \\
\text { tion }\end{array}$ & $\begin{array}{l}\text { Barium } \\
\text { enema }\end{array}$ & $\mathrm{O}$ & $\begin{array}{l}\text { Intussuscep } \\
\text { tion }\end{array}$ & $\begin{array}{l}\text { Adenomyoma } \\
\text { tous } \\
\text { hamartoma }\end{array}$ \\
\hline 9 & $\begin{array}{l}\text { Scrour [ } \\
20]\end{array}$ & $\begin{array}{l}199 \\
4\end{array}$ & $\begin{array}{l}3 \\
\text { years }\end{array}$ & male & $\begin{array}{l}\text { Foreign } \\
\text { body post } \\
\text { reduction } \\
\text { by air } \\
\text { enema }\end{array}$ & $\mathrm{X}$ ray & $\mathrm{x}$ & $\begin{array}{l}\text { Intestinal } \\
\text { intramural } \\
\text { mass }\end{array}$ & adenomyoma \\
\hline 10 & $\begin{array}{l}\text { Chan [21 } \\
\text { ] }\end{array}$ & $\begin{array}{l}199 \\
4\end{array}$ & $\begin{array}{l}5 \\
\text { mont } \\
\text { hs }\end{array}$ & $\begin{array}{l}\text { Fema } \\
\text { le }\end{array}$ & ND & ND & 0 & $\begin{array}{l}\text { Intussuscep } \\
\text { tion }\end{array}$ & adenomyoma \\
\hline 11 & $\begin{array}{l}\text { Chan [21 } \\
\text { ] }\end{array}$ & $\begin{array}{l}199 \\
4\end{array}$ & $\begin{array}{l}3 \\
\text { years }\end{array}$ & Male & ND & ND & $\mathrm{X}$ & $\begin{array}{l}\text { Incidental } \\
\text { findings }\end{array}$ & adenomyoma \\
\hline 12 & $\begin{array}{l}\text { Gonzalve } \\
\mathrm{z}[22]\end{array}$ & $\begin{array}{l}199 \\
5\end{array}$ & $\begin{array}{l}2 \\
\text { years }\end{array}$ & Male & $\begin{array}{l}\text { Intussuscep } \\
\text { tion }\end{array}$ & $\begin{array}{l}\text { Pneumoen } \\
\text { ema }\end{array}$ & 0 & $\begin{array}{l}\text { Intussuscep } \\
\text { tion }\end{array}$ & $\begin{array}{l}\text { Myoepithelial } \\
\text { hamartoma }\end{array}$ \\
\hline 13 & $\begin{array}{l}\text { Tanaka } \\
{[23]}\end{array}$ & $\begin{array}{l}199 \\
6\end{array}$ & $\begin{array}{l}24 \\
\text { years }\end{array}$ & Male & $\begin{array}{l}\text { Submucosa } \\
1 \text { ileal } \\
\text { tumor }\end{array}$ & $\begin{array}{l}\text { Small } \\
\text { bowel } \\
\text { barium } \\
\text { study }\end{array}$ & $\mathrm{X}$ & melena & $\begin{array}{l}\text { Myoepithelial } \\
\text { hamartoma }\end{array}$ \\
\hline 14 & $\begin{array}{l}\text { Yamaga } \\
\text { mi [ 24] }\end{array}$ & $\begin{array}{l}199 \\
7 \\
\end{array}$ & $\begin{array}{l}4 \\
\text { mont }\end{array}$ & Male & $\begin{array}{l}\text { Intussuscep } \\
\text { tion }\end{array}$ & $\begin{array}{l}\text { Barium } \\
\text { enema }\end{array}$ & 0 & $\begin{array}{l}\text { Intussuscep } \\
\text { tion }\end{array}$ & $\begin{array}{l}\text { Myoepithelial } \\
\text { hamartoma }\end{array}$ \\
\hline
\end{tabular}




\begin{tabular}{|c|c|c|c|c|c|c|c|c|c|}
\hline & & & hs & & & & & & \\
\hline 15 & $\begin{array}{l}\text { Ueyama } \\
{[25]}\end{array}$ & $\begin{array}{l}200 \\
1\end{array}$ & $\begin{array}{l}52 \\
\text { years }\end{array}$ & $\begin{array}{l}\text { Fema } \\
\text { le }\end{array}$ & $\begin{array}{l}\text { Peritonitis } \\
\text { caused by } \\
\text { perforated } \\
\text { appenditciti } \\
\text { S }\end{array}$ & $\begin{array}{l}\text { Abdominal } \\
\text { CT }\end{array}$ & $\mathrm{X}$ & Peritonitis & adenomyoma \\
\hline 16 & $\begin{array}{l}\text { Park [ } \\
26]\end{array}$ & $\begin{array}{l}200 \\
3\end{array}$ & $\begin{array}{l}7 \\
\text { mont } \\
\text { hs }\end{array}$ & Male & $\begin{array}{l}\text { Intussuscep } \\
\text { tion }\end{array}$ & $\begin{array}{l}\text { Abdominal } \\
\text { ultrasound }\end{array}$ & ND & $\begin{array}{l}\text { Intussuscep } \\
\text { tion }\end{array}$ & adenomyoma \\
\hline 17 & $\begin{array}{l}\text { Mourava } \\
\text { s [ 27] }\end{array}$ & $\begin{array}{l}200 \\
3\end{array}$ & $\begin{array}{l}18 \\
\text { mont } \\
\text { hs }\end{array}$ & Male & $\begin{array}{l}\text { Intussuscep } \\
\text { tion }\end{array}$ & $\begin{array}{l}\text { Abdominal } \\
\text { ultrasound }\end{array}$ & 0 & $\begin{array}{l}\text { Intussuscep } \\
\text { tion }\end{array}$ & adenomyoma \\
\hline 18 & $\begin{array}{l}\text { Takahash } \\
\text { i [28 ] }\end{array}$ & $\begin{array}{l}200 \\
6\end{array}$ & $\begin{array}{l}75 \\
\text { years }\end{array}$ & Male & ND & ND & ND & $\begin{array}{l}\text { Autopsy } \\
\text { findings }\end{array}$ & adenomyoma \\
\hline 19 & $\begin{array}{l}\text { Takeda [ } \\
29 \text { ] }\end{array}$ & $\begin{array}{l}201 \\
0\end{array}$ & $\begin{array}{l}68 \\
\text { years }\end{array}$ & Male & $\begin{array}{l}\text { Small } \\
\text { bowel } \\
\text { obstruction }\end{array}$ & $\begin{array}{l}\text { Abdominal } \\
\text { CT }\end{array}$ & 0 & $\begin{array}{l}\text { Intussuscep } \\
\text { tion }\end{array}$ & adenomyoma \\
\hline 20 & Bak[ 30] & $\begin{array}{l}201 \\
3\end{array}$ & $\begin{array}{l}11 \\
\text { mont } \\
\text { hs }\end{array}$ & $\begin{array}{l}\text { femal } \\
\text { e }\end{array}$ & $\begin{array}{l}\text { Intussuscep } \\
\text { tion }\end{array}$ & $\begin{array}{l}\text { Abdominal } \\
\text { ultrasound }\end{array}$ & 0 & $\begin{array}{l}\text { Intussuscep } \\
\text { tion }\end{array}$ & adenomyoma \\
\hline $\begin{array}{l}\text { Prese } \\
\text { nt } \\
\text { case }\end{array}$ & $\begin{array}{l}\text { Elguazza } \\
\mathrm{r}\end{array}$ & $\begin{array}{l}201 \\
9\end{array}$ & $\begin{array}{l}28 \\
\text { years }\end{array}$ & $\begin{array}{l}\text { femal } \\
\text { e }\end{array}$ & $\begin{array}{l}\text { Intussuscep } \\
\text { tion }\end{array}$ & $\begin{array}{l}\text { Abdominal } \\
\text { CT }\end{array}$ & $\mathrm{x}$ & $\begin{array}{l}\text { Intussuscep } \\
\text { tion }\end{array}$ & adenomyoma \\
\hline
\end{tabular}

The pathogenesis of adenomyoma has not been fully elucidated. Its histopathological findings are characterized by glandular structures lined by a cuboidal to tall columnar epithelium surrounded by bundles of smooth muscle cells; however, the histogenesis of the condition is disputed. The most widely accepted hypothesis is that these lesions represent a form of myoepithelial hamartoma or a type III pancreatic heterotopia [17, 31]. In this study, immunohistochemical examination was performed in an attempt to increase our understanding of the pathogenesis of adenomyoma. As a result, we detected the expression of CK 7 and CA19-9 and the absence of CK 20 expression, which are similar to the characteristics of the pancreatic duct epithelium. Judging from these results and the absence of MUC 2 expression, it is suggested that the glandular component of our case was not composed of intestinal epithelial cells, but rather of pancreatic duct epithelial cells. Our case was diagnosed as adenomyoma of the ileum, therefore in our opinion the pathogenesis of this lesion supports the heterotopic pancreas theory.

\section{Conclusion:-}

Finally, we consider that adenomyoma of the ileum is a rare cause of intussusception in all age groups.It is also suggested that adenomyoma is a form of heterotopic pancreatic tissue.

Our case is distinguished by the fact that it is rare to find an adenomyoma of the ileum complicated by intussusception with intestinal obstruction in the adult age group.

\section{References:-}

1. De Moulin D, Paul Barbette MD. A 17th-century Amsterdam author of best-selling textbooks. Bull Hist Med $1985 ; 59: 506-14$.

2. Huang BY, Warshauer DM. Adult intussusception: diagnosis and clinical relevance. Radiol Clin North Am 2003; 41:1137-51.

3. Lebeau R, Koffi E, Diané B, Amani A, Kouassi JC. Invaginations intestinales aiguës de l'adulte: analyse d'une série de 20 cas. Ann Chir. 2006; 131: 447-50.

4. Fournier R, Gouzien P, Russier Y, Garola P, Veillard JM. Intestinal intussusception in adults: contribution of ultrasonography. J Chir (Paris). 1994 Oct;131(10):430-3.

5. Wang N, Cui XY, Liu Y, Long J, Xu YH, Guo RX, et al. Adult intussusception: a retrospective review of 41 cases. World J Gastroenterol 2009;15:3303-8.

6. Marinis A, Yiallourou A, Samanides L, Dafnios N, Anastasopoulos G, Vassiliou I, et al. Intussusception of the bowel in adults: a review. World J Gastroenterol 2009;15:407-11. 
7. Dean AJ, Lafferty K, Villanueva TC. Emergency medicine bedside ultrasound diagnosis of intussusception in a patient with chronic abdominal pain and unrecognized Peutz-Jeghers syndrome. J Emerg Med 2003;24:20310.

8. Weilbaecher D, Bolin JA, Hearn D, Ogden W: Intussusception in adults. Review of 160 cases. Am J Surg 1971;121:531-535.

9. Nagorney DM, Sarr MG, McIlrath DC: Surgical management of intussusception in the adult. Ann Surg 1981;193:230-236.

10. Zubaidi A, Al-Saif F, Silverman R: Adult intussusception: a retrospective review. Dis Colon Rectum 2006;49:1546-1551.

11. Yalamarthi S, Smith RC: Adult intussusception: case reports and review of literature. Postgrad Med J 2005;81:174-177.

12. Zhu HN, Yu JP, Luo J, Jiang YH, Li JQ, Sun WY (2010) Gastric adenomyoma presenting as melena; a case report and literature review. World J Gastroenterol 16(15):1934-1936.

13. Schwartz SI, Radwin HM: Myoepithelial hamartoma of the ileum causing intussusception. AMA Arch Surg 1958;77:102-104.

14. Benisch B, Peison B: Adenoma of the ileum. Am J Obstet Gynecol 1978;131:582-584.

15. Rosenmann E, Maayan C, Lernau O: Leiomyomatous hamartosis with congenital jejunoileal atresia. Isr J Med Sci 1980;16:775-779.

16. Gal R, Kolkow Z, Nobel M: Adenomyomatous hamartoma of the small intestine: a rare cause of intussusceptions in an adult. Am J Gastroenterol 1986;12:1209-1211.

17. Kim CJ, Choe GY, Chi JG: Foregut choristoma of the ileum (adenomyoma) - a case report. Pediatr Pathol 1990;10:799-805.

18. Gal R, Rath-Wolfson L, Ginzburg M, Kessler E: Adenomyomas of the small intestine. Histopathology 1991;18:369-371.

19. Lamki N, Woo CL, Watson AB Jr, Kim HS: Adenomyomatous hamartoma causing ileoileal intussusception in a young child. Clin Imaging 1993;17:183-185.

20. Serour F, Gorenstein A, Lipnitzky V, Zaidel L: Adenomyoma of the small bowel: a rare cause of intussusceptions in childhood. J Pediatr Gastroenterol Nutr 1994;18:247-249.

21. Chan YF, Roche D: Adenomyoma of the small intestine in children. J Pediatr Surg 1994;29:1611-1612.

22. Gonzalvez J, Marco A, Andujar M, Iniguez L: Myoepithelial hamartoma of the ileum: a rare case of intestinal intussusceptions in children. Eur J Pediatr Surg 1995;5:303-304.

23. Tanaka N, Seya T, Onda M, Kanazawa Y, Naitoh Z, Asano G, Hao K: Myoepithelial hamartoma of the small bowel: report of a case. Surg Today 1996;26:1010-1013.

24. Yamagami T, Tokiwa K, Iwai N: Myoepithelial hamartoma of the ileum causing intussusceptions in an infant. Pediatr Surg Int 1997;12:206-207.

25. Ueyama N, Kuwashima S, Nakayama A, Nakanishi K, Okuchi K, Kagoshima T, Nakajima Y: Ileal adenomyoma accompanied by primary peritonitis. Surg Today 2001;31:826-829.

26. Park HS, Lee SO, Lee JM, Kang MJ, Lee DG, Chung MJ: Adenomyoma of small intestine: report of two cases and review of the literature. Pathol Int 2003;53:111-114.

27. Mouravas V, Koutsoumis G, Patoulias J, Kostopoulos I, Kottakidou R, Kallergis K, Kepertis C, Liolios N: Adenomyoma of the small intestine in children: a rare cause of intussusception: a case report. Turk J Pediatr 2003;45:345-347.

28. Takahashi Y, Fukushima J, Fukusato T, Shigeo M: Adenomyoma with goblet and Paneth cells of the ileum. Pathol Res Pract 2006; 202:549-553.

29. Takedaa M, Shojib T, Yamazakib M: Adenomyoma of the Ileum Leading to Intussusception . Case Rep Gastroenterol 2011; 5:602-609.

30. Bak et al.: Adenomyoma of the small intestine a rare pathological lead point for intussusception in an infant. SpringerPlus 2014 3:616.

31. Qing X, Petrie BA, Buslon V, French S: Adenomyoma of the jejunum. Exp Mol Pathol 2009;86:127-130. 